\title{
Evaluation of neck blast resistance and agronomical performances on double haploid rice population in greenhouse and endemic field
}

\author{
GUT WINDARSIH ${ }^{1, \bullet}$, DWINITA WIKAN UTAMI ${ }^{2, \bullet \bullet}$ \\ ${ }^{1}$ Faculty of Education and Teacher Training, UIN Sultan Maulana Hasanuddin. Jl. Raya Syeikh Nawawi Bantani, Kemanisan, Curug, Serang City 42171, \\ Banten, Indonesia. Tel.: +62-254-200323, `email: gut.windarsih@uinbanten.ac.id \\ ${ }^{2}$ Indonesian Center for Agricultural Biotechnology and Genetic Resource Research and Development. Jl. Tentara Pelajar No. 3A, Bogor 16111, West \\ Java, Indonesia. Tel. +62-251-8337975, Fax. +62-251-8338820, “^email: dnitawu@windowslive.com.
}

Manuscript received: 17 July 2016. Revision accepted: 17 November 2017.

\begin{abstract}
Windarsih G, Utami DW. 2017. Evaluation of neck blast resistance and agronomical performances on double haploid rice population in greenhouse and endemic field. Nusantara Bioscience 9: 371-377. Blast disease caused by fungal Pyricularia grisea Sacc. is one of the most destructive diseases of rice in the world. The development of blast-resistant rice varieties will be essential to control this disease. This research aimed (i) to compare the resistance response to neck-blast among DH lines from double cross IR54/Parekaligolara//Bio110/Markuti and the differential varieties against three selected Indonesian blast races in greenhouse, (ii) to identify the gene(s) that caused the resistance to neck-blast based on the association between the resistance response and the genotype evaluation using molecular markers linked to Pi1, Pi33, Pib, Pir4 and Pir7 genes, and (iii) to evaluate the resistance response to leaf and neck blast on DH lines in endemic field (Sukabumi) and the agronomical performance of selected DH lines in optimum field in Ciasem of Subang, West Java, Indonesia during December 2013 to March 2014. Eleven double haploid lines from double-crossing IR54/Parekaligolara//Bio110/Markuti, the differential varieties as resistant control and the US2 variety for susceptible control were observed for neck-blast resistance response to three blast races in greenhouse and endemic field (Sukabumi), while the agronomical performances were observed in field of Ciasem-Subang. The results based on the genotyping evaluation, leaf and neck blast resistance, either in greenhouse and endemic location, and the agronomical performance in field showed that 5 selected double haploid lines had leaf and neck blast resistance and good performance on field trial. Thus they are promising for use either for further testing forwarding into releasing variety or used as donor for further blast resistant breeding activities.
\end{abstract}

Keywords: Double haploid population, field evaluation, greenhouse, neck blast resistance, rice

\section{INTRODUCTION}

Rice is a staple food of the most population of the world including Indonesia. Biotic and abiotic stresses are the major constraints to increase the rice productivity (Akhtar et al. 2010). One of the biotic stresses in rice is blast disease. Blast disease caused by fungal Pyricularia grisea Sacc. (the teleomorph is Magnaporthe grisea, the synonym is Pyricularia oryzae Cavara) is one of the most destructive diseases (Zhu et al. 2005), therefore it is an important disease on rice (Kumar et al. 2010; Rossman et al. 1990).

Pyricularia grisea commonly attacks the leaves causing leaf blast during the vegetative growth stage or the panicle node causing neck blast during the reproductive stage (Bonman et al. 1992). Ou (1985) reported that there is no correlation between leaf and neck blast infection with the resistance genes that involved. Certain rice cultivars that are resistant to leaf blast on vegetative stage could be susceptible to neck blast at generative growth stage, and conversely, the cultivars that susceptible to leaf blast can show a little or no neck blast attack.

Pyricularia grisea is dynamic. It is capable to adapt rapidly to the host condition. This pathogen also has a high genetic diversity and the capability to produce new races rapidly (Utami et al. 2011). More than 26 races of $P$. grisea fungal have been identified from endemic blast area in
Indonesia, seven races of them, i.e., races 001, 023, 033, $073,101,133$ and 173, are the most dominant races that always infect plants in every growing season (Santoso and Nasuton 2009). Therefore, the development of blastresistant rice varieties with durable resistance and in polygenic constitution is essential to control this disease (Utami et al. 2011). One of the strategies to overcome the multi-races blast pathogen is by developing blast resistant varieties that have the resistance genes through breeding program (Utami et al. 2005).

The Indonesian Center for Agricultural Biotechnology and Genetic Resource Research and Development (ICABIOGRAD), Bogor, Indonesia had produced 49 double haploids (DH) lines from an anther culture into F1 generation plants from double crossing of IR54/Parekaligolara//Bio110/Markuti. IR54 variety tolerates to phosphate deficiency and resists to blast simultaneously. IR54 was tested with molecular markers linked to blast resistance genes of Pi1, Pi2, Pi9, Pi33, and Pib. Bio110 was resistant to blast and had the blast resistance genes of Pir4 and Pir7. These genes were detected by using the molecular markers on the backcross mapping population from a cross of IR64/Oryza rufipogon (Utami et al. 2008). Parekaligolara was resistant to the bacterial leaf blight disease, while Markuti was tolerant to Fe toxicity stress. Windarsih et al. (2014) reported that by 
using the molecular markers into DH lines from double cross IR54/Parekaligolara//Bio110/Markuti, it was found that $P i b$ gene caused leaf-blast resistance to race 123 , while Pi1 and Pir7 genes to races 123 and 133. Pi2, Pi9, Pi33 and Pir4 genes did not cause leaf-blast resistance to races 123,133 or 173 . The aims of this research were: (i) to compare the resistance response to neck-blast among $\mathrm{DH}$ lines derived from double cross IR54/Parekaligolara// Bio110/Markuti and the differential varieties against three selected Indonesian blast races in greenhouse, (ii) to identify the gene (s) causing the resistance to neck-blast based on the association between the resistance response and the genotype evaluation using molecular markers linked to Pi1, Pi33, Pib, Pir4 and Pir7 genes, and (iii) to evaluate the resistance response to leaf and neck blast on DH lines in endemic field of Sukabumi District, West Java, Indonesia; and the field agronomical performance of selected DH lines in Ciasem, Subang District, West Java, Indonesia.

\section{MATERIALS AND METHODS}

\section{Plant materials}

The genetic materials used in this research were $11 \mathrm{DH}$ lines derived from double crossing of IR54/Parekaligolara// Bio110/Markuti (IPBM-2-3-2, BMIP-20-2-1-1-1, IPBM32-2-1-1-2, IPBM-32-1-2-1-1, BMIP-40-2-1-1, BMIP-402-1-2, BMIP-24-1-4-2, BMIP-15-4-2-1, BMIP-46-4-1, IPBM-32-1-2-3-1, and IPBM-32-1-3-3), the differential varieties consisted of 7 monogenic lines from LTH (Lijiang-xin-tuan-heigu) genetic background which were detected to have blast-resistance gene (IRBLz5-CA [Piz gene], IRBLta-CT2 [Pita gene], IRBLsh-S [Pish gene], IRBL1-CL [Pi1 gene], IRBL5-M [Pi5 gene], IRBLkm-Ts [Pikm gene], IRBLi-F5 [Pii gene]) as resistant control, and US2 variety for a susceptible control. The $\mathrm{DH}$ lines were selected as medium resistant and resistant to leaf-blast infection according to the previous research by Windarsih et al. (2014). Each plant was tested for neck-blast resistance response to races 123, 133 and 173 (Table 1).

\section{Procedures}

The neck-blast resistance evaluation in greenhouse

All rice seeds were induced for germination in water for three days. The seedlings were grown in plastic pots (sized $35 \mathrm{~cm} \times 25 \mathrm{~cm} \times 10 \mathrm{~cm}$ ) filled with paddy soil media. Three seeds per line were planted. After five weeks, the plants were moved into polybag filled with paddy field soil with three plants per polybag, one variety per polybag, and then grown until producing panicle.

Each race of $P$. grisea was grown on a potato dextrose agar (PDA) medium. After seven days, the isolate was grown in an oatmeal medium to produce conidia. On the tenth day, the fungus colony on the surface of oatmeal medium was rubbed with a drawing brush and streptomycin $0.01 \%$ in sterile water to prohibit the bacteria growth. The isolate was stored in an incubator with a fluorescent lamp illumination of 20 watts for 48 hours to induce the conidia production. After illumination, the oatmeal medium contained conidia of $P$. grisea were sliced in $1 \mathrm{~cm} \mathrm{x} 1 \mathrm{~cm}$ for neck blast inoculation.

Agar slices containing conidia of $P$. grisea were placed on aluminium foil and wrapped on base panicle of tested plants. The inoculated plants were incubated in a greenhouse. The humidity was maintained by watering treatment with a sprinkler system (Windarsih et al. 2014). After one week, the aluminium foil was removed, then the neck blast infection was scored on a scale of $0-9$, which $0=$ no infected-blast panicle, 1 = less than $5 \%$ of infected-blast panicles, $3=5-10 \%$ of infected-blast panicles, $5=11-25 \%$ of infected-blast panicles, $7=26-50 \%$ of infected-blast panicles, $9=$ more than $50 \%$ of infected-blast panicles. Plants were classified based on the incidence rates of panicles exhibiting neck blast as follows: Resistant (R) with $0-10 \%$ of infected-blast panicle, Moderately Resistant (MR) with 11-25\% and Susceptible (S) with 26-100\% (IRRI 2002). The observation was conducted 4 times at one-week interval. Meanwhile, the area under disease progress curve (AUDPC) was calculated using a formula suggested by Shaner and Finney (1977):

$$
\begin{aligned}
& \text { AUDPC }=\sum_{i=1}^{n-1}\left[\left(\frac{x_{1+2}+x_{1}}{2}\right)\right]\left[t_{1+1}-t_{i j}\right] \\
& \text { IUDPC }=\left(\left(\frac{x_{1}+x_{2}}{2}\right) x\left(t_{2}-t_{1}\right)\right)+\left(\left(\frac{x_{2}+x_{2}}{2}\right) x\left(t_{g}-t_{2}\right)\right)+\left(\left(\frac{x_{2}+x_{4}}{2}\right) x\left(t_{4}-t_{g}\right)\right)
\end{aligned}
$$

Wherein: $\mathrm{X}_{1}=$ the incidence rates of panicles exhibiting neck blast on the first observation ( $7^{\text {th }}$ day), $X_{2}=$ the incidence rates of panicle exhibiting neck blast on the second observation ( $14^{\text {th }}$ day), $\mathrm{X}_{3}=$ the incidence rates of panicle exhibiting neck blast on the third observation $\left(21^{\text {th }}\right.$ day), $\mathrm{X}_{4}=$ the incidence rates of panicle exhibiting neck blast on the fourth observation ( $28^{\text {th }}$ day), $t_{1}=$ the time of days on first week observation, $t_{2}=$ the time of days on second week observation, $t_{3}=$ the time of days on third week observation, $t_{4}=$ the time of days on fourth week observation.

Table 1. The identity of blast races that used for neck-blast inoculation.

\begin{tabular}{lllllll}
\hline Race & $\begin{array}{l}\text { Location of } \\
\text { Collection }\end{array}$ & $\begin{array}{l}\text { Year of } \\
\text { Collection }\end{array}$ & Number of Isolate & Host & Mating Type & ACE-1 vir Gene \\
\hline 123 & Lampung & 2004 & ID22 & Cirata & - & PH14 (vir2) \\
133 & Lampung & 2003 & ID23 & Cirata & $1-2$ & PH14 (vir2) \\
173 & Lampung & 2003 & ID24 & Cirata & $1-2$ & PH14 (vir2) \\
\hline
\end{tabular}


Blast resistance observation in endemic location, Sukabumi All plants were planted with a randomized block design at a width of $60 \mathrm{~cm}$ and three repetitions per line. Each line was planted in a plot. The distance between plots/lines was $10 \mathrm{~cm}$. The susceptible control of US2 was planted after every 20 lines. The roadside plant, resistant and susceptible, were planted two weeks earlier than tested double haploid lines. The observation of leaf and neck blast attack was conducted on early and late growth duration. The leaf blast infection was scored on a scale according to IRRI (1996) and Windarsih et al. (2014).

\section{Yield component observation in field location of Ciasem, Subang}

All plants were planted with a randomized block design with three repetitions per line. Each line was planted in a plot ( $1 \mathrm{~m} \times 2 \mathrm{~m}=4$ lines $\times 8$ lines). The plant age when planting was 21 days, one seedling per hill with a spacing of $25 \mathrm{~cm} \mathrm{x} 25 \mathrm{~cm}$. The agronomical performances that observed consisted of date to flowering, date to harvesting, plant height, total tiller, panicle length, total grain, and thousand grains weight (Table 2).

\section{Data analysis}

The association between the genotype evaluation using molecular markers (Windarsih et al. 2014) and the neck blast resistant response was analyzed with Tassel 2.0 Program. The marker (s) that was associated with the neck blast resistant response (p_value under 0.05) was assumed this marker (s) could be used as the selection marker for the neck resistance gene; it showed that this gene caused a resistance to neck blast.

\section{RESULTS AND DISCUSSION}

\section{Neck blast resistance evaluation}

The reaction pattern to neck blast at the end of observation (Table 3) showed that the differential varieties that had Pita, Pi5, Pikm or Pii genes were resistant to race 123, while the ones having Piz, Pish or Pi1 genes were medium resistant. This shows that all those genes recognized the aggression of race 123 on panicle and continued to initiate a defense system in plants. The differential varieties that had Pish or Pikm genes were resistant to race 173 , while the ones having Piz, Pita, Pi1 or Pi5 genes were medium resistant; Pii gene was susceptible. Meanwhile, race 133 was the most aggressive to attack panicle. The differential varieties that had Piz, Pita and Pikm genes were resistant to race 133, while the ones having Pi1 gene was medium resistant. This shows that those genes recognized the aggression of race 133 on panicle and continued to initiate a defense system in plants, in contrast, Pish, Pi5 or Pii genes bearer varieties were susceptible to race 133 . Meanwhile, on DH lines, 8 lines were resistant to race 123, 2 lines were medium resistant, and 1 line was susceptible. Ten lines were resistant to race 133, while 1 line was medium resistant. Seven lines were resistant to race 173, 3 lines were medium resistant, while 1 line was susceptible (Table 3).

The latent period to neck-blast infection was observed in this research. The latent period is the time interval between the infection of spore and the appearance of disease symptoms. On differential varieties, IRBLsh-S, IRBL5-M and IRBLi-F5 lines had a short-latent period to race 133 (7 days after inoculation), it showed these lines were susceptible to the race. IRBLi-F5 lines also had a short-latent period to race 173 (7 days after inoculation), therefore this line was susceptible to this race. Meanwhile, on DH lines, IPBM-32-1-2-1-1 line had a short-latent period to race 123 (7 days after inoculation), therefore this line was susceptible to this race. BMIP-40-2-1-1 line had a short-latent period to race 173 (7 days after inoculation), therefore this line was susceptible to this race. US2 variety was had a short-latent period (7 days after inoculation) to all inoculated races, therefore this variety was susceptible to races 123, 133 and 173 (Table 3).

The percentages of neck blast attack on differential varieties and DH haploid lines are shown in Table 4. The results showed that the average of AUDPC value on the differential varieties to race 123 was about $20.00 \%$, to race 133 was $31.00 \%$ and to race 173 was $26.00 \%$. In another side, the average of AUDPC value on DH lines to race 123 was $15.91 \%$, to race 133 was $6.36 \%$ and to race 173 was $17.50 \%$. It had a meaning that race 173 had the broadest virulence spectrum to attack the base panicle causing a neck blast on tested $\mathrm{DH}$ lines, while race 133 had the broadest virulence spectrum to attack the base panicle causing a neck blast on differential varieties. These results were different with the leaf blast response on differential varieties obtained by Windarsih et al. (2014), in which race 173 had the broadest virulence spectrum to cause the leaf blast. Meanwhile, this response was similar to the leaf blast response on $\mathrm{DH}$ lines, in which race 173 had the broadest virulence spectrum to cause the leaf blast.

Table 2. Rice traits observed for agronomical performances in field location of Ciasem, Subang (Baurley et al. 2014; IRRI 2014).

\begin{tabular}{lll}
\hline Traits & Units & Description \\
\hline $\begin{array}{l}\text { Date to flowering } \\
\begin{array}{l}\text { Date to harvesting } \\
\text { Plant height }\end{array}\end{array}$ & $\begin{array}{l}\text { day } \\
\text { day } \\
\text { Total tiller }\end{array}$ & $\begin{array}{l}\text { days after planting when 50\% of the plants have flowers } \\
\text { days after planting until physiological maturity } \\
\text { Panicle length } \\
\begin{array}{l}\text { Total grain } \\
\text { Thousand grains weight }\end{array}\end{array}$ \\
\hline
\end{tabular}


Table 3. The reaction pattern of differential varieties to neck blast inoculated by three selected blast isolates for observations at oneweek interval.

\begin{tabular}{|c|c|c|c|c|c|c|c|c|c|c|c|c|}
\hline \multirow{3}{*}{ Lines } & \multicolumn{12}{|c|}{ The observation of reaction pattern to neck blast at one-week interval } \\
\hline & \multicolumn{4}{|c|}{ Race 123} & \multicolumn{4}{|c|}{ Race 133} & \multicolumn{4}{|c|}{ Race 173} \\
\hline & 1 & 2 & 3 & 4 & 1 & 2 & 3 & 4 & 1 & 2 & 3 & 4 \\
\hline IRBLz5-CA & $0 / \mathrm{R}$ & $1 / \mathrm{R}$ & $3 / \mathrm{R}$ & 5/MR & $0 / \mathrm{R}$ & $0 / \mathrm{R}$ & $1 / \mathrm{R}$ & $3 / \mathrm{R}$ & $0 / \mathrm{R}$ & $1 / \mathrm{R}$ & $3 / \mathrm{R}$ & 5/MR \\
\hline IRBLta-CT2 & $0 / \mathrm{R}$ & $0 / \mathrm{R}$ & $1 / \mathrm{R}$ & $3 / \mathrm{R}$ & $0 / \mathrm{R}$ & $0 / \mathrm{R}$ & $1 / \mathrm{R}$ & $3 / \mathrm{R}$ & $0 / \mathrm{R}$ & $1 / \mathrm{R}$ & $3 / R$ & 5/MR \\
\hline IRBLsh-S & $0 / \mathrm{R}$ & $1 / \mathrm{R}$ & $3 / \mathrm{R}$ & 5/MR & $1 / \mathrm{R}$ & $3 / \mathrm{R}$ & 5/MR & $7 / S$ & $0 / \mathrm{R}$ & $0 / \mathrm{R}$ & $0 / \mathrm{R}$ & $1 / \mathrm{R}$ \\
\hline IRBL1-CL & $0 / \mathrm{R}$ & $1 / \mathrm{R}$ & $3 / \mathrm{R}$ & 5/MR & $0 / \mathrm{R}$ & $1 / \mathrm{R}$ & $3 / \mathrm{R}$ & 5/MR & $0 / \mathrm{R}$ & $1 / \mathrm{R}$ & $3 / R$ & 5/MR \\
\hline IRBL5-M & $0 / \mathrm{R}$ & $0 / \mathrm{R}$ & $1 / \mathrm{R}$ & $3 / \mathrm{R}$ & $1 / \mathrm{R}$ & $3 / \mathrm{R}$ & 5/MR & 7/S & $0 / \mathrm{R}$ & $1 / \mathrm{R}$ & $3 / R$ & 5/MR \\
\hline IRBLkm-Ts & $0 / \mathrm{R}$ & $0 / \mathrm{R}$ & $1 / \mathrm{R}$ & $3 / \mathrm{R}$ & $0 / \mathrm{R}$ & $0 / \mathrm{R}$ & $0 / \mathrm{R}$ & $0 / \mathrm{R}$ & $0 / \mathrm{R}$ & $0 / \mathrm{R}$ & $0 / \mathrm{R}$ & $0 / \mathrm{R}$ \\
\hline IRBLi-F5 & $0 / \mathrm{R}$ & $0 / \mathrm{R}$ & $0 / \mathrm{R}$ & $1 / \mathrm{R}$ & $1 / \mathrm{R}$ & $3 / \mathrm{R}$ & 5/MR & $7 / S$ & $1 / \mathrm{R}$ & $3 / \mathrm{R}$ & 5/MR & $7 / S$ \\
\hline IPBM-2-3-2 & $0 / \mathrm{R}$ & $0 / \mathrm{R}$ & $0 / \mathrm{R}$ & $1 / \mathrm{R}$ & $0 / \mathrm{R}$ & $0 / \mathrm{R}$ & $0 / \mathrm{R}$ & $0 / \mathrm{R}$ & $0 / \mathrm{R}$ & $1 / \mathrm{R}$ & $3 / \mathrm{R}$ & 5/MR \\
\hline BMIP-20-2-1-1-1 & $0 / \mathrm{R}$ & $0 / \mathrm{R}$ & $1 / \mathrm{R}$ & $3 / \mathrm{R}$ & $0 / \mathrm{R}$ & $0 / \mathrm{R}$ & $0 / \mathrm{R}$ & $0 / \mathrm{R}$ & $0 / \mathrm{R}$ & $0 / \mathrm{R}$ & $1 / \mathrm{R}$ & $3 / \mathrm{R}$ \\
\hline IPBM-32-2-1-1-2 & $0 / \mathrm{R}$ & $1 / \mathrm{R}$ & $3 / \mathrm{R}$ & 5/MR & $0 / \mathrm{R}$ & $0 / \mathrm{R}$ & $0 / \mathrm{R}$ & $0 / \mathrm{R}$ & $0 / \mathrm{R}$ & $0 / \mathrm{R}$ & $0 / \mathrm{R}$ & $0 / \mathrm{R}$ \\
\hline IPBM-32-1-2-1-1 & $1 / \mathrm{R}$ & $3 / \mathrm{R}$ & 5/MR & $7 / S$ & $0 / \mathrm{R}$ & $0 / \mathrm{R}$ & $0 / \mathrm{R}$ & $1 / \mathrm{R}$ & $0 / \mathrm{R}$ & $0 / \mathrm{R}$ & $0 / \mathrm{R}$ & $1 / \mathrm{R}$ \\
\hline BMIP-40-2-1-1 & $0 / \mathrm{R}$ & $0 / \mathrm{R}$ & $1 / \mathrm{R}$ & $3 / \mathrm{R}$ & $0 / \mathrm{R}$ & $0 / \mathrm{R}$ & $0 / \mathrm{R}$ & $1 / \mathrm{R}$ & $1 / \mathrm{R}$ & $3 / \mathrm{R}$ & 5/MR & $7 / S$ \\
\hline BMIP-40-2-1-2 & $0 / \mathrm{R}$ & $0 / \mathrm{R}$ & $1 / \mathrm{R}$ & $3 / \mathrm{R}$ & $0 / \mathrm{R}$ & $0 / \mathrm{R}$ & $0 / \mathrm{R}$ & $1 / \mathrm{R}$ & $0 / \mathrm{R}$ & $0 / \mathrm{R}$ & $0 / \mathrm{R}$ & $0 / \mathrm{R}$ \\
\hline BMIP-24-1-4-2 & $0 / \mathrm{R}$ & $1 / \mathrm{R}$ & $3 / \mathrm{R}$ & 5/MR & $0 / \mathrm{R}$ & $0 / \mathrm{R}$ & $1 / \mathrm{R}$ & $3 / \mathrm{R}$ & $0 / \mathrm{R}$ & $1 / \mathrm{R}$ & $3 / \mathrm{R}$ & 5/MR \\
\hline BMIP-15-4-2-1 & $0 / \mathrm{R}$ & $0 / \mathrm{R}$ & $1 / \mathrm{R}$ & $3 / \mathrm{R}$ & $0 / \mathrm{R}$ & $0 / \mathrm{R}$ & $1 / \mathrm{R}$ & $3 / \mathrm{R}$ & $0 / \mathrm{R}$ & $0 / \mathrm{R}$ & $1 / \mathrm{R}$ & $3 / \mathrm{R}$ \\
\hline BMIP-46-4-1 & $0 / \mathrm{R}$ & $0 / \mathrm{R}$ & $0 / R$ & $0 / \mathrm{R}$ & $0 / \mathrm{R}$ & $0 / \mathrm{R}$ & $0 / \mathrm{R}$ & $0 / \mathrm{R}$ & $0 / \mathrm{R}$ & $1 / \mathrm{R}$ & $3 / \mathrm{R}$ & 5/MR \\
\hline IPBM-32-1-2-3-1 & $0 / \mathrm{R}$ & $0 / \mathrm{R}$ & $0 / \mathrm{R}$ & $0 / \mathrm{R}$ & $0 / \mathrm{R}$ & $0 / \mathrm{R}$ & $0 / \mathrm{R}$ & $0 / \mathrm{R}$ & $0 / \mathrm{R}$ & $0 / \mathrm{R}$ & $1 / \mathrm{R}$ & $3 / \mathrm{R}$ \\
\hline IPBM-32-1-3-3 & $0 / \mathrm{R}$ & $0 / \mathrm{R}$ & $0 / \mathrm{R}$ & $0 / \mathrm{R}$ & $0 / \mathrm{R}$ & $1 / \mathrm{R}$ & $3 / R$ & 5/MR & $0 / \mathrm{R}$ & $0 / \mathrm{R}$ & $0 / \mathrm{R}$ & $0 / \mathrm{R}$ \\
\hline US2 & $1 / \mathrm{R}$ & $3 / \mathrm{R}$ & 5/MR & $7 / S$ & $1 / \mathrm{R}$ & $3 / \mathrm{R}$ & 5/MR & $7 / S$ & $1 / \mathrm{R}$ & $3 / \mathrm{R}$ & 5/MR & $7 / \mathrm{S}$ \\
\hline
\end{tabular}

Note: $\mathrm{R}=$ resistant, $\mathrm{MR}=$ medium resistant, $\mathrm{S}=$ susceptible, $1^{\text {st }}$ observation $=7$ days after inoculation, $2^{\text {nd }}$ observation $=14$ days after inoculation, $3^{\text {rd }}$ observation $=21$ days after inoculation, $4^{\text {th }}=28$ days after inoculation

Table 4. AUDPC value from three selected isolates on the differential varieties, double haploid population and the susceptible control (US2).

\begin{tabular}{lccc}
\hline \multirow{2}{*}{ Line } & \multicolumn{3}{c}{ AUDPC (\%) } \\
\cline { 2 - 4 } & Race 123 & Race 133 & Race 173 \\
\hline IRBLz5-CA & 31.50 & 14.00 & 31.50 \\
IRBLta-CT2 & 14.00 & 14.00 & 31.50 \\
IRBLsh-S & 31.50 & 52.50 & 3.50 \\
IRBL1-CL & 31.50 & 31.50 & 31.50 \\
IRBL5-M & 14.00 & 52.50 & 31.50 \\
IRBLkm-Ts & 14.00 & 0 & 0 \\
IRBLi-F5 & 3.50 & 52.50 & 52.50 \\
Average & $\mathbf{2 0 . 0 0}$ & $\mathbf{3 1 . 0 0}$ & $\mathbf{2 6 . 0 0}$ \\
& & & \\
IPBM-2-3-2 & 3.50 & 0 & 31.50 \\
IPBM-32-1-2-1-1 & 14.00 & 0 & 14.00 \\
IPBM-32-1-2-3-1 & 31.50 & 0 & 0 \\
IPBM-32-1-3-3 & 52.50 & 3.50 & 3.50 \\
IPBM-32-2-1-1-2 & 14.00 & 3.50 & 52.50 \\
BMIP-15-4-2-1 & 14.00 & 3.50 & 0 \\
BMIP-20-2-1-1-1 & 31.50 & 14.00 & 31.50 \\
BMIP-24-1-4-2 & 14.00 & 14.00 & 14.00 \\
BMIP-40-2-1-1 & 0 & 0 & 31.50 \\
BMIP-40-2-1-2 & 0 & 0 & 14.00 \\
BMIP-46-4-1 & 0 & 31.50 & 0 \\
Average & $\mathbf{1 5 . 9 1}$ & $\mathbf{6 . 3 6}$ & $\mathbf{1 7 . 5 0}$ \\
US2 & & & \\
\hline
\end{tabular}

\section{Association analysis of molecular markers with reaction pattern to neck blast}

The resistance to blast pathogen is controlled by the resistance gene in the host. The presence of this resistance gene can be identified using molecular markers. The genotype evaluation using eight primers to amplify the targeted DNA fragments as markers for Pi1, Pi33, Pib, Pir4 and Pir7 genes were obtained by Windarsih et al. (2014).

The molecular markers associated with the resistance to neck blast pathogen race (s) could be used as the marker for the existence of resistance genes. These genes were responsible to the resistance to the blast pathogen race. The association between molecular markers and reaction pattern of DH lines to neck blast attack showed that only PiSNP7 primer associated with the neck blast resistance to race 133 with $\mathrm{p}$-value $=0.0178(\mathrm{p}<0.05)$. This primer amplified DNA fragments marking on Pir7 gene. It showed that PiSNP7 primer could be used as selection marker for Pir7 gene caused the resistance response to neck blast attack by race 133. There was no association between markers RM138, RM166, RM208, RM266, RM224, G1010 and PiSNP4 with the targeted $P i$ gene; therefore, they could not be used as selection markers for targeted genes caused resistance to neck blast infection. All DH lines produced marker band of Pir7 gene using PiSNP7 primer, while in another side, all DH lines were resistant or medium resistant to neck blast attack inoculated by race 133 . It reveals that all DH lines had Pir7 gene contributed to the resistance to neck blast inoculated by race 133 . This gene 
could recognize the protein produced by the virulence (avr) gene from race 133 . However, this gene did not cause a resistance to neck blast caused by race 123 and 173 . The pathogen attack ability was influenced by the virulence factor possessed by a certain race of blast pathogen. It occurs in the interaction between the blast resistance gene in host and the virulence gene (avr) in the blast pathogen (Bohnert et al. 2004).

Pyricularia grisea has the virulence gene namely ACE1-avr gene. This gene codes the poly-keto synthetase protein and contained 4035 amino acids which catalyzed the pathogen penetration in host (Bohnert. et al 2004). ACE1 has two copies of genes that show the different genotypes of blast isolates. There are three genotypes of blast isolates, i.e. Guy11 (ACE1-vir), CM28 (ACE1-vir1) and $\mathrm{PH} 14$ (ACE1-vir2) genotypes. Guy11 genotype has one ACE1 copy gene in chromosome 1 of blast genome which is virulent. CM28 genotype has one ACE1 copy gene in chromosome 6, which is virulent. Meanwhile, PH14 genotype has two copies of ACE1 gene, Guy11 and CM28 (Couch et al. 2005).

Pir7 gene was the QTL (quantitative trait loci) detected on backcross mapping population from crossing between IR64 and Oryza rufipogon. It originated from IR64 and was mapped by using PiSNP7 primer at $122.8 \mathrm{cM}$ positions (Utami et al. 2008). Race 133 contained PH14 avr gene with two ACE1 copy genes in chromosomes 1 and 6 (Santoso et al. 2007). This research is in line with Utami et al. (2007) that Pir7 gene was resistant to blast isolate that had $\mathrm{PH} 14$ avr gene and susceptible to blast isolate that had CM28 avr gene.

\section{Blast resistance observation in endemic location, Sukabumi}

Field observation results showed that there were five selected double haploid lines: IPBM-2-3-2, IPBM-32-1-21-1, BMIP-24-1-4-2, BMIP-40-2-1-1, and BMIP-40-2-1-2 as the most resistant to leaf and neck blast based on the evaluation, either in greenhouse and endemic field of Sukabumi (Table 5). In greenhouse evaluation, IPBM-2-32, BMIP-40-2-1-1 and BMIP-40-2-1-2 were resistant/medium resistant to all of leaf and neck blast races inoculated. IPBM-32-1-2-1-1 was medium resistant to leaf blast race 133 but susceptible to race 123 and 173, and resistant to all inoculated neck blast races. BMIP-24-1-4-2 was medium resistant to leaf blast race 123 and resistant to race 133 , but susceptible to race 173; it was resistant to the three inoculated neck blast races. Field test in endemic location of Sukabumi (Figure 1) showed that those five selected lines were resistant to leaf blast, either on early and late growth stage, except for IPBM-2-3-2 that was medium resistant. On later growth stage, IPBM-32-1-2-1-1 was resistant to neck blast, BMIP-24-1-4-2, BMIP-40-2-11 and BMIP-40-2-1-2 were medium resistant, and IPBM-23-2 was susceptible. Those five selected lines were detected to have Pir7 gene that was responsible for the resistance to leaf (Windarsih et al. 2014) and neck blast.

Table 5. Blast resistance performance of 5 selected double haploid lines in greenhouse test during January-April 2013 and in field test, Sukabumi, West Java, Indonesia during December 2013-March 2014.

\begin{tabular}{|c|c|c|c|c|c|c|c|c|c|c|}
\hline \multirow{3}{*}{$\begin{array}{l}\text { Double haploid } \\
\text { lines }\end{array}$} & \multicolumn{6}{|c|}{ Green house test } & \multicolumn{3}{|c|}{ Sukabumi field test } & \multirow{3}{*}{$\begin{array}{l}\text { Pi gene } \\
\text { detected }\end{array}$} \\
\hline & \multicolumn{3}{|c|}{ Leaf blast score* } & \multicolumn{3}{|c|}{ Neck blast score } & \multirow{2}{*}{$\begin{array}{c}\text { Early stage } \\
\text { Leaf blast } \\
\text { score }\end{array}$} & \multicolumn{2}{|c|}{ Late stage } & \\
\hline & R 123 & R 133 & R 173 & R 123 & R 133 & R 173 & & $\begin{array}{c}\text { Leaf blast } \\
\text { Score }\end{array}$ & $\begin{array}{l}\text { Neck blast } \\
\text { Score } \\
\end{array}$ & \\
\hline IPBM-2-3-2 & 3/MR & 3/MR & 3/MR & $1 / \mathrm{R}$ & $0 / \mathrm{R}$ & 5/MR & $1 / \mathrm{R}$ & 5/MR & $7 / S$ & Pir7 \\
\hline IPBM-32-1-2-1-1 & $4 / S$ & 3/MR & $4 / \mathrm{S}$ & $3 / \mathrm{R}$ & $0 / \mathrm{R}$ & $3 / \mathrm{R}$ & $0 / \mathrm{R}$ & $0 / \mathrm{R}$ & $1 / \mathrm{R}$ & Pir7 \\
\hline BMIP-24-1-4-2 & 3/MR & $0 / \mathrm{R}$ & $4 / S$ & $1 / \mathrm{R}$ & $3 / \mathrm{R}$ & $3 / \mathrm{R}$ & $3 / \mathrm{R}$ & $1 / \mathrm{R}$ & 5/MR & Pir7 \\
\hline BMIP-40-2-1-1 & 3/MR & $1 / \mathrm{R}$ & 3/MR & $0 / \mathrm{R}$ & $0 / \mathrm{R}$ & 5/MR & $1 / \mathrm{R}$ & $1 / \mathrm{R}$ & 5/MR & Pir7 \\
\hline BMIP-40-2-1-2 & 3/MR & $1 / \mathrm{R}$ & 3/MR & $0 / \mathrm{R}$ & $0 / \mathrm{R}$ & 3/R & $0 / \mathrm{R}$ & $0 / \mathrm{R}$ & 5/MR & Pir7 \\
\hline
\end{tabular}

Note: *Windarsih et al. (2014), in which the leaf blast response was scored according to Hayashi et al. (2009).

Table 6. Agronomical performance of 5 selected double haploid lines that the most resistant to leaf and neck blast in Ciasem, Subang during December 2013-March 2014.

\begin{tabular}{lccccccc}
\hline Double haploid lines & $\begin{array}{c}\text { Date to } \\
\text { flowering (days) }\end{array}$ & $\begin{array}{c}\text { Date to } \\
\text { harvesting } \\
\text { (days) }\end{array}$ & $\begin{array}{c}\text { Plant height } \\
\text { (cm) }\end{array}$ & Total tillering & $\begin{array}{c}\text { Panicle } \\
\text { length (cm) }\end{array}$ & $\begin{array}{c}\text { Total grain } \\
\text { (grams) }\end{array}$ & $\begin{array}{c}\text { Thousand grains } \\
\text { weight (grams) }\end{array}$ \\
\hline IPBM-2-3-2 & 79 & $\mathbf{1 0 5}$ & 90.5 & $\mathbf{1 9}$ & 24.4 & 117 & 24 \\
IPBM-32-1-2-1-1 & 83 & 111 & 89.4 & 16 & 24.3 & $\mathbf{1 8 5}$ & 29 \\
BMIP-24-1-4-2 & 79 & 109 & $\mathbf{8 7}$ & 16 & 24.7 & 154 & 27 \\
BMIP-40-2-1-1 & 88 & 114 & 102 & 17 & $\mathbf{2 9 . 4}$ & 161 & 27 \\
BMIP-40-2-1-2 & $\mathbf{7 5}$ & 107 & $\mathbf{8 7}$ & 17 & 22.3 & 111 & 24 \\
\hline
\end{tabular}




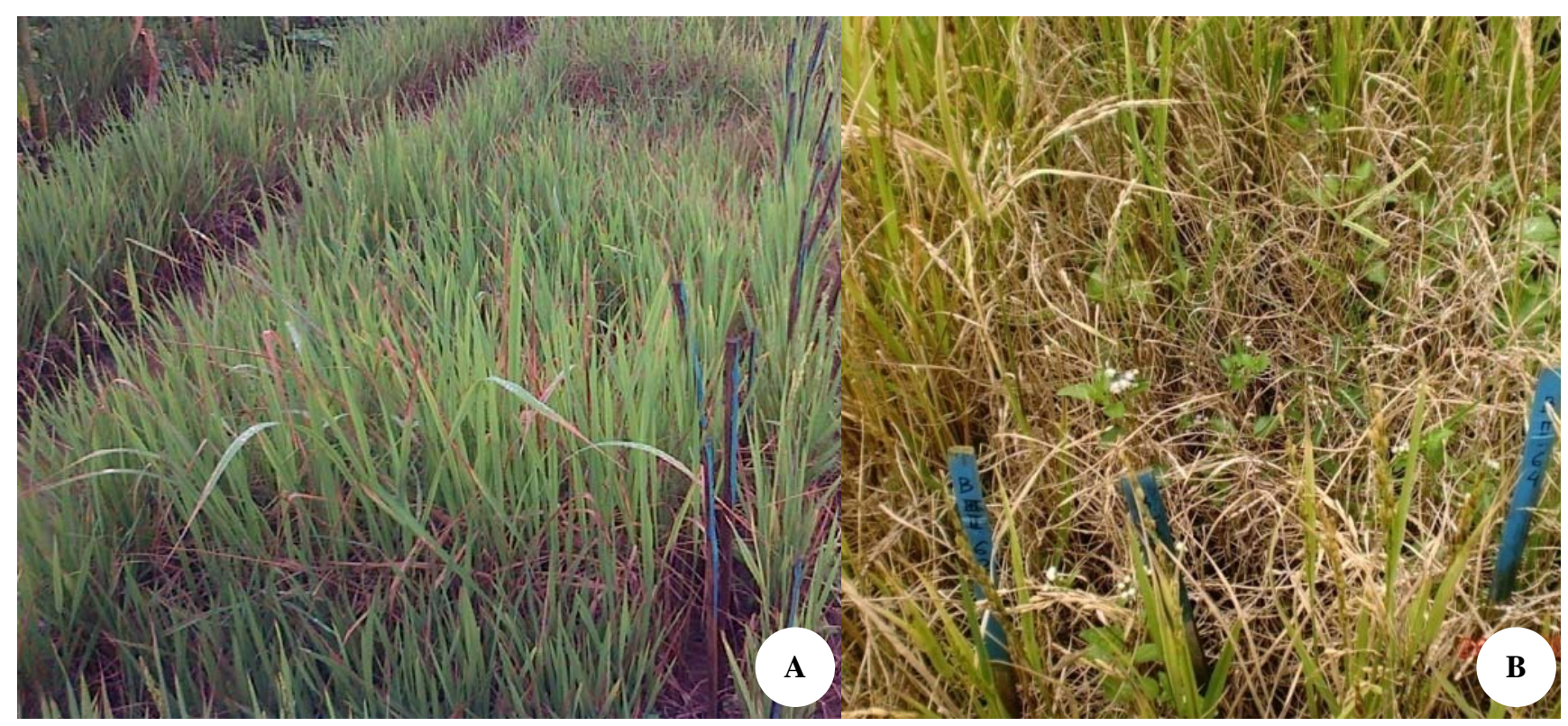

Figure 1. Blast resistance observation in endemic area of Sukabumi, West Java, Indonesia. A. The early growth stage with leaf blast infection, B. The late growth stage with the neck blast infection

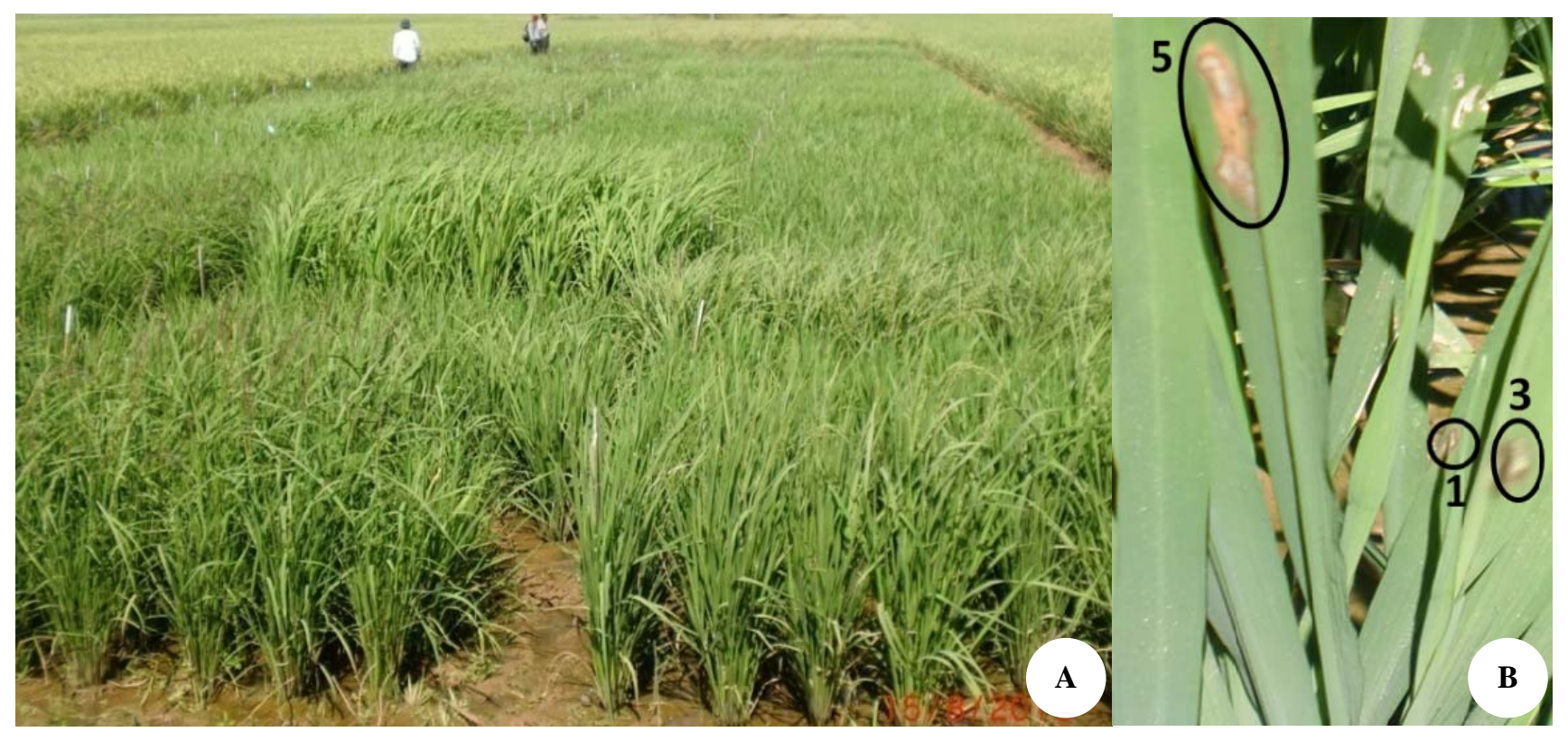

Figure 7. A. Field performance of tested haploids and differential varieties for blast resistance in Ciasem, Subang, West Java, Indonesia during December 2013-April 2014; B. Leaf blast symptoms on tested plant for score 1, 3 and 5 (Hayashi et al. 2009)

\section{Yield component observation in field location of Ciasem, Subang}

The agronomical performance of 5 selected double haploid lines that planted in Ciasem, Subang, were shown in Table 6. Among these selected lines, IPBM-2-3-2 was the earliest maturing lines (105 days after sowing) and produced a highest total tillering (19 tillering). IPBM-32-12-1-1 produced the highest total grains/hill (185 g) and one thousand grain weight (29 g). BMIP-24-1-4-2 had shortest plant height $(87 \mathrm{~cm})$ that can protect the plant from lodging due to wind. Meanwhile, BMIP-40-2-1-2 had also the earliest heading date (75 days after sowing). The selection of variety is not only considered the resistance to leaf and neck blast, either on greenhouse and field test, but also the agronomical performance.

Based on either greenhouse and endemic field test result, it was identified five double haploid lines resistant to leaf and neck blast, i.e. IPBM-2-3-2, IPBM-32-1-2-1-1, 
BMIP-24-1-4-2, BMIP-40-2-1-1, BMIP-40-2-1-2. These lines had good agronomical performance and therefore were promising for further testing and utilization.

\section{ACKNOWLEDGEMENTS}

We thank Wawan and Yana Suryatna from ICABIOGRAD, Bogor, Indonesia for assistance with Pyricularia grisea fungus and plant material preparation. This research was funded by the Indonesian Center for Agricultural Biotechnology and Genetic Resource Research and Development (ICABIOGRAD), Bogor, with the contract number of 1798.011.002.013 in 2013.

\section{REFERENCES}

Akhtar S, Bhat MA, Wani SA, Bhat KA, Chalkoo S, Mir MR, Wani SA. 2010. Marker-assisted selection in rice. J Phytol 2 (10): 66-81.

Baurley JW, Pardamean B, Perbangsa AS, Utami DW, Rijzaani H, Satyawan D. 2014. A bioinformatics workflow for genetic association studies of traits in Indonesian rice. In: Linawati et al. (eds). ICTEurAsia, Bali, 14-17 April 2014.

Bohnert HU, Fudal I, Dioh W, Tharreau D, Notteqhem JL, Lebrun MH. 2004. A putative polyketide synthase/peptide synthetase from Magnaporthe grisea signals pathogen attack to resistant rice. Plant Cell 16 (9): 2499-2513. DOI: 10.1105/tpc.104.022715.

Bonman JM, Khush GS, Nelson RJ. 1992. Breeding rice for resistance to pests. Ann Rev Phytopathol 30: 507-528.

Couch BC, Fudal I, Lebrun MH, Tharreau D, Valent B, van Kim P, Nottéghem JL, Kohn LM. 2005. Origins of host-specific populations of the blast pathogen Magnaporthe oryzae in crop domestication with subsequent expansion of pandemic clones on rice and weeds of rice. Genetics 170: 613-630.

Hayashi N, Kobayashi N, Cruz CMV, Fukuta Y. 2009. Protocol for the sampling of diseased specimens and evaluation of blast disease in rice. Development and Characterization of Blast Resistance using Differential Varieties in Rice. Japan International Research Center for Agricultural Sciences (JIRCAS), Tsukuba.
IRRI [International Rice Research Institute]. 2002. Standard evaluation system for rice (SES). IRRI, Metro Manila, Philippines.

IRRI [International Rice Research Institute]. 1996. Standart Evaluation System for Rice. $4^{\text {th }}$ edition. IRRI, Philippines.

IRRI [International Rice Research Institute]. 2014. Standard evaluation system for rice (SES). IRRI, Metro Manila, Philippines.

Kumar A, Kumar S, Kumar R, Kumar V, Prasad L, Kumar N, Singh D. 2010. Identification of blast resistance expression in rice genotypes using molecular markers (RAPD and SCAR). Africa J Biotechnol 9: 3501-3509.

Ou SH. 1985. Rice Diseases, $2^{\text {nd }}$ edition. Commonwealth Agricultural Bureaux, UK.

Rossman, Howard, Valent. 1990. Pyricularia grisea, the correct name for the rice blast disease fungus. Mycologia 82: 509-512.

Santoso, Nasution A, Utami DW, Hanarida I, Ambarwati AD, Moeljopawiro S, Tharreau D. 2007. Variasi genetik dan spektrum virulensi patogen blas pada padi asal Jawa Barat dan Sumatera. Penelitian Pertanian Tanaman Pangan 26(3): 150-155. [Indonesian]

Santoso, Nasution A. 2009. Pengendalian penyakit blas dan penyakit cendawan lainnya. BB Padi, Subang. [Indonesian]

Shaner G, Finney R. 1977. The effect of nitrogen fertilization on the expression of slow-mildewing in knox wheat. Phytopathol 67: 10511056.

Utami DW, Ambarwati AD, Apriana A, Sisharmini A, Hanarida I, Tharreau D, Santosa. 2007. Spektrum ketahanan galur haploid ganda turunan IR64 dan Oryza rufipogon yang mengandung QTL ketahanan terhadap penyakit blas (Pir). J AgroBiogen 3 (1): 1-8. [Indonesian]

Utami DW, Moeljopawiro S, Hanarida I, Tharreau D. 2008. Fine mapping of rice blast QTL from Oryza rufipogon and IR64 by SNP markers. Sabrao 40 (2): 105-115.

Utami DW, Moeljopawiro S, Aswidinnoor H, Setiawan A, Hanarida I. 2005. Gen pengendali sifat ketahanan penyakit blas (Pyricularia grisea Sacc.) pada spesies padi liar Oryza rufipogon Griff. dan padi budi daya IR64. AgroBiogen 1 (1):1-6.

Utami DW, Barnita K, Yuriah S, Hanarida I. 2011. Nucleotide base variation of blast disease resistance gene Pi33 in rice selected broad genetic background. Hayati 18 (3): 123-128.

Windarsih G, Utami DW, Widyastuti U. 2014. Molecular markers application for blast resistance selection on the double haploid rice population. Makara J Sci 18 (2): 31-41.

Zhu YY, Fang H, Wang YY, Fan JX, Yang SS, Mew TW, Mundt CC. 2005. Panicle blast and canopy moisture in rice cultivar mixtures. Phytopathol 95: 433-438. 